\title{
Prediction of default probability in banking industry using CAMELS index: A case study of Iranian banks
}

\author{
Mohammad Khodaei Valahzaghard $^{\mathrm{a}^{*}}$ and Maryam Bahrami
}

\begin{abstract}
${ }^{a}$ Assist. Prof. \& Faculty Member, Department of Accounting, School of Management and Human Sciences, Tehran North Branch, Islamic Azad University (IAU), Tehran, Iran

${ }^{b}$ M.Sc. Student, Department of Accounting, School of Management and Human Scienc-es, Tehran North Branch, Islamic Azad University (IAU), Tehran, Iran

\section{H R O N I C L E}

Article history:

Received December 2, 2012

Received in revised format

10 March 2013

Accepted 14 March 2013

Available online

March 142013

Keywords:

CAMELS

Default Probability

Capital Adequacy

\section{A B S T R A C T}

This study examines the relationship between CAMELS index and default probability among 20 Iranian banks. The proposed study gathers the necessary information from their financial statements over the period 2005-2011. The study uses logistic regression along with Pearson correlation analysis to consider the relationship between default probability and six independent variables including capital adequacy, asset quality, management quality, earning quality, liquidity quality and sensitivity of market risk. The results indicate that there were no meaningful relationship between default probability and three independent variables including capital adequacy, asset quality and sensitivity of market risk. However, the results of our statistical tests support such relationship between default probability and three other variables including management quality, earning quality and liquidity quality.
\end{abstract}

Earning Quality

\section{Introduction}

The CAMEL ratings system is a technique of assessing the health of credit unions by the National Credit Union Administration(NCUA) (Basel Committee on Banking Supervision, 2005; Bessis, 2005; Vassalou \& Xing, 2004). The rating is based on five critical elements of a credit union's operations including capital, asset quality, management, earnings and asset liability management. Measuring the effects of default probability plays an important role on making managerial financial decisions and there are literally many studies associated with this issue. Zeitun et al. (2007) investigated the impact of cash flow and free cash flow on corporate failure in the emerging market in particular Jordan using. They used the information of two samples including matched sample and a cross-sectional time-series over the period 1989-2003. They also used LOGIT models to study the relationship between firms' financial health and the probability of default. They reported that there was firm's free

Corresponding author. Tel: +98-912-3443139

E-mail: m_khodaei@iau-tnb.ac.ir (M. Khodaei Valahzaghard)

C 2013 Growing Science Ltd. All rights reserved.

doi: $10.5267 / \mathrm{j} . \mathrm{ms} 1.2013 .03 .016$ 
cash flow increases corporate failure and firm's cash flow decreased corporate failure. While firms' capital structures played essential role on predicting default, capital structure was observed as the main factor influencing the probability of default as it affected a firm's ability to access external sources of funds. They concluded that Jordanian firms depended on short-term debt for both short and long term financing.

According to Osherson et al. (1991), A probability is normally called "default" if it is neither derived from pre-established probabilities nor based on considerations of frequency or symmetry. Default probabilities is assumed to occur through reasoning based on causality and similarity. Osherson et al. (1991) advanced a technique of default probability based on a featural method to similarity and examined the accuracy of the model by comparing its predictions to the probabilities provided by undergraduates asked to reason about mammals.

Boyes et al. (1989) recommended that the traditional view that emphasizes default probability was too narrow and their model of credit assessment concentrated on expected earnings. They explained how maximum likelihood estimates of default probabilities could be achieved from a bivariate 'censored probit' framework based on a 'choice-based' sample originally intended for discriminant analysis. They concluded with recommendations for combining these default probability estimated with other parameters of the loan earnings process to compute a more meaningful model of credit assessment. Finally, Zhou (2001) in an investigation analyzed the relationship between default correlations and multiple defaults.

\section{The proposed study}

The proposed study of this paper examines the relationship between CAMELS index and default probability (Chiu, 2005) among 20 Iranian banks. The proposed study gathers the necessary information from their financial statements over the period 2005-2011. The study uses logistic regression along with Pearson correlation analysis to consider the relationship between default probability and six independent variables including capital adequacy, asset quality, management quality, earning quality, liquidity quality and sensitivity of market risk (Fiordelisi et al., 2010). The proposed study uses the following regression model,

$D P_{i, t}=\beta_{0}+\beta_{1} C A_{i, t}+\beta_{2} A Q_{i, t}+\beta_{3} M Q_{i, t}+\beta_{4} E Q_{i, t}+\beta_{5} L Q_{i, t}+\beta_{6} S M_{i, t}+\varepsilon_{i}$,

where $D P_{i, t}$ represents default probability as dependent variable and $C A_{i, t}, \beta_{2} A Q_{i, t}, M Q_{i, t}, \beta_{4} E Q_{i, t}$, $L Q_{i, t}$ and $S M_{i, t}$ are capital adequacy, asset quality, management quality, earning quality, liquidity quality and sensitivity of market risk, respectively. In addition $\beta_{i}, i=0, \ldots, 6$ represent coefficients to be estimated and $\varepsilon_{i}$ represents residuals.

As stated, the proposed study uses the information of 20 different banks and Table 1 demonstrates the information of these banks in terms of ownership types in various years.

\section{Table 1}

The information of ownership type

\begin{tabular}{lcccccccc}
\hline Ownership & 2005 & 2006 & 2007 & 2008 & 2009 & 2010 & 2011 & Total \\
\hline Governmental & 9 & 9 & 9 & 9 & 10 & 7 & 7 & 60 \\
Private & 7 & 7 & 7 & 7 & 7 & 13 & 13 & 61 \\
\hline Total & 16 & 16 & 16 & 16 & 17 & 20 & 20 & 121 \\
\hline
\end{tabular}

As we can observe from the results of Table 1, the number of private banks has been increased from 7 to 13 over the period 2005-2011 and part of is due to privatization efforts accomplished by government. In addition, Table 2 demonstrates the results of some basic statistics on the data. 
Table 2

The summary of some basic statistics

\begin{tabular}{lcccc}
\hline & $\mathrm{N}$ & Mean & Std. Deviation & Variance \\
Statistic & Statistic & 0.139 & 0.019 \\
\hline SA & 121 & 0.116 & 6.762 & 45.725 \\
AQ & 121 & 14.074 & 0.304 & 0.437 \\
MQ & 121 & 0.590 & 0.239 & 0.057 \\
EQ & 121 & 0.474 & 0.208 & 0.043 \\
LQ & 121 & 0.538 & 8.575 & 73.541 \\
SM & 121 & 13.034 & 0.502 & 0.252 \\
DP & 121 & 0.50 & & \\
\hline
\end{tabular}

We first perform Kolmogorov-Smirnov to understand whether the data are normally distributed or not and the results of observation are summarized in Table 3 as follows,

Table 3

The summary of Kolmogorov-Smirnov

\begin{tabular}{lccc}
\hline & $\mathrm{N}$ & Statistics & Level of significance \\
\hline CA & 121 & 3.039 & .000 \\
AQ & 121 & .791 & .558 \\
MQ & 121 & 2.762 & .000 \\
EQ & 121 & 1.848 & .002 \\
LQ & 121 & 2.339 & .000 \\
SM & 121 & .748 & .631 \\
DP & 121 & 3.767 & 0.000 \\
\hline
\end{tabular}

The results of Table 3 show that five variables of capital adequacy, management quality, earning quality, liquidity quality and default probability are not normally distributed but two variables of assets quality and default probability are normally distributed. We also need to make sure there is no strong correlations among independent variables and this can be accomplished using VIF test summarized in Table 4 as follows,

Table 4

The summary of VIF test

\begin{tabular}{lccc}
\hline & $\mathrm{N}$ & Statistics & Level of significance \\
\hline CA & 121 & 2.770 & .361 \\
AQ & 121 & 2.391 & .418 \\
MQ & 121 & 1.593 & .628 \\
EQ & 121 & 1.800 & .555 \\
LQ & 121 & 1.219 & .820 \\
SM & 121 & 1.535 & .651 \\
\hline
\end{tabular}

As we can observe from the results of Table 4, the VIF value for the first two items, capital adequacy and asset quality are greater than 2 and we can conclude there is a correlation between these two variables, which is mainly because of the existing inflation rate. However, according to VIF test results, the other variables are not linearly correlated.

\section{The results}

In this section, we present details of our investigation on testing various hypotheses and this survey. We first perform Pearson correlation test between default probability and six independent variables using the following hypothesis,

$\left\{\begin{array}{l}H_{0}: \rho=0 \\ H_{1}: \rho \neq 0\end{array}\right.$ 
where the null hypothesis states there is no correlation and alternative hypothesis states there is a correlation between default probability and independent variable. Table 5 demonstrates the results of our survey,

Table 5

The summary of Pearson correlation test

\begin{tabular}{lccc}
\hline & $\mathrm{N}$ & Statistics & Level of significance \\
\hline CA & 121 & 0.146 & .109 \\
AQ & 121 & -0.143 & .143 \\
MQ & 121 & -0.218 & .0216 \\
EQ & 121 & -0.262 & .004 \\
LQ & 121 & 0.180 & .048 \\
SM & 121 & 0.115 & .208 \\
\hline
\end{tabular}

The results of Table 5 show that there is a meaningful relationship between earning quality, management quality as well as liquidity quality and default probability and there is no meaningful relationship default probability and capital adequacy, asset quality as well as sensitivity management and default probability. We have also investigated correlation ratio between independent variables and Table 6 summarizes the results of our survey.

Table 6

The summary of correlation test

\begin{tabular}{llcccccc}
\hline Variable & & CA & AQ & MQ & EQ & LQ & SM \\
\hline \multirow{2}{*}{ CA } & Coefficient & 1 & -0.711 & 0.580 & -0.375 & 0.594 & -0.513 \\
& P-Value & & 0.000 & 0.000 & 0.000 & 0.000 & 0.000 \\
\hline \multirow{2}{*}{ AQ } & Coefficient & -0.991 & 1 & -0.443 & 0.255 & -0.280 & 0.587 \\
& P-Value & 0.000 & & 0.000 & 0.005 & 0.002 & 0.000 \\
\hline \multirow{2}{*}{ MQ } & Coefficient & 0.493 & -0.493 & 1 & 0.122 & 0.582 & -0.149 \\
& P-Value & 0.000 & 0.000 & & 0.182 & 0.000 & 0.102 \\
\hline \multirow{2}{*}{ EQ } & Coefficient & -0.208 & 0.193 & 0.267 & 1 & 0.094 & 0.654 \\
& P-Value & 0.022 & 0.034 & 0.003 & & 0.304 & 0.000 \\
\multirow{2}{*}{ LQ } & Coefficient & 0.248 & -0.261 & 0.490 & 0.406 & 1 & 0.042 \\
& P-Value & 0.006 & 0.004 & 0.000 & 0.000 & & 0.647 \\
\multirow{2}{*}{ SM } & Coefficient & -0.538 & 0.537 & -0.036 & 0.684 & 0.269 & \\
& P-Value & 0.000 & 0.000 & 0.696 & 0.000 & 0.003 & \\
\hline
\end{tabular}

According to the results of Table 6, there are some meaningful relationships correlation between CA and AQ, MQ, EQ, LQ and SM. There is also a meaningful relationship between AQ and MQ, LQ and $\mathrm{SM}$ when the level of significance is five or even one percent.

The main hypothesis of this survey investigates whether we can predict default probability using CAMEL indexes or not. Therefore, we study the following hypothesis,

$\left\{\begin{array}{l}H_{0}: \beta_{X_{1}, \ldots, X_{10}}=0 \\ H_{1}: \beta_{X_{1}, \ldots, X_{10}} \neq 0\end{array}\right.$

In order to test the above hypothesis, we use "Omnibus Tests of Model Coefficients" statistical test. Table 7 summarizes the results of our survey.

Table 7

The summary of Omnibus Tests of Model Coefficients test

\begin{tabular}{ccccc}
\hline & & Chi-square & Df & Sig. \\
\hline \multirow{3}{*}{ Step 1 } & Step & 16.902 & 6 & 0.010 \\
& Block & 16.902 & 6 & 0.010 \\
& Model & 16.902 & 6 & 0.010 \\
\hline
\end{tabular}


The results of Omnibus Tests of Model Coefficients test indicate that independent variable influences dependent variable, significantly and we can precede the regression analysis. The results of Cox \& Snell R Square and Nagelkerke R Square are 0.128 and 0.171 , respectively. Therefore, we can perform the regression analysis and the results are summarized in Table 8 as follows,

\section{Table 8}

The summary of logistic regression analysis

\begin{tabular}{ccccccc}
\hline Variable & B & S.E. & Wald & Df & Sig. & Exp(B) \\
\hline Constant & 0.687 & 1.432 & 0.230 & 1 & 0.613 & 1.988 \\
CA & -3.257 & 3.043 & 1.146 & 1 & 0.284 & 0.038 \\
AQ & -.026 & 0.052 & 0.261 & 1 & 0.610 & 0.974 \\
MQ & -1.552 & 0.920 & 2.847 & 1 & 0.092 & 0.212 \\
EQ & -3.132 & 1.588 & 3.890 & 1 & 0.047 & 0.044 \\
LQ & 5.004 & 2.270 & 4.858 & 1 & 0.028 & 148.998 \\
SM & -.017 & 0.040 & 0.183 & 1 & 0.669 & 0.983 \\
\hline
\end{tabular}

In Table 8, the column B represents the estimated coefficients of the proposed study. We have used the results of regression analysis and Table 9 shows the percentages of default and non-default probabilities.

\section{Table 9}

The results of default and non-default

\begin{tabular}{ccccc}
\hline & & \multicolumn{2}{c}{ Regression results } & \multicolumn{2}{c}{ Correct percentage } \\
\cline { 3 - 5 } & & Non-default & default & 63.1 \\
\hline Default regression & Non-default & 36 & 24 & 66.7 \\
\hline & Default & 20 & 41 & 67.4 \\
\hline
\end{tabular}

According to the results of Table 9, default and non-default are predicted, properly with the probabilities of $66.7 \%$ and $63.1 \%$, respectively. The results of Table 8 also indicate that three variables were not statistically significant and using stepwise regression technique, we modify the model and the results are summarized as follows,

Table 10

The summary of logistic regression analysis

\begin{tabular}{ccccccc}
\hline Variable & B & S.E. & Wald & Df & Sig. & Exp(B) \\
\hline Constant & 0.104 & 0.950 & 0.12 & 1 & 0.913 & 1.110 \\
MQ & -1.508 & 0.898 & 2.819 & 1 & 0.093 & 0.221 \\
EQ & -2.800 & 1.153 & 5.900 & 1 & 0.015 & 0.061 \\
LQ & 3.969 & 1.912 & 4.308 & 1 & 0.038 & 52.930 \\
\hline
\end{tabular}

In Table 10, the column B represents the estimated coefficients of the proposed study. We have used the results of regression analysis and Table 11 shows the percentages of default and non-default probabilities.

\section{Table 11}

The results of default and non-default

\begin{tabular}{ccccc}
\hline & & \multicolumn{2}{c}{ Regression results } & \multirow{2}{*}{ Correct percentage } \\
\cline { 3 - 5 } & & Non-default & default & \\
\hline \multirow{2}{*}{ Default regression } & Non-default & 33 & 27 & 66.1 \\
& Default & 21 & 40 & 65.6 \\
\hline Total percentage & & & & 67.8 \\
\hline
\end{tabular}

According to the results of Table 11, default and non-default are predicted, properly with the probabilities of $66.1 \%$ and $65.6 \%$, respectively. The results indicate that there are no meaningful 
relationship between default probability and three independent variables including capital adequacy, asset quality and sensitivity of market risk. However, the results of our statistical tests support such relationship between default probability and three other variables including management quality, earning quality and liquidity quality. Table 12 summarizes the results of our regression analysis.

Table 12

The summary of testing six hypotheses, Dependent variable $=$ Default probability (DP)

\begin{tabular}{|c|c|c|c|c|c|c|}
\hline \multirow[b]{2}{*}{ Hypothesis } & \multicolumn{2}{|c|}{ Variables } & \multicolumn{3}{|c|}{ Regression analysis } & \multirow[b]{2}{*}{ Result } \\
\hline & Dependent & Independent & $\beta_{X}=0$ & $\beta_{X} \neq 0$ & Path & \\
\hline First & DP & $\mathrm{CA}$ & $\sqrt{ }$ & $x$ & - & Not-confirmed \\
\hline Second & DP & AQ & $\sqrt{ }$ & $x$ & - & Not-confirmed \\
\hline Third & DP & MQ & $x$ & $\sqrt{ }$ & - & Confirmed \\
\hline Fourth & DP & EQ & $x$ & $\sqrt{ }$ & - & Confirmed \\
\hline Fifth & DP & LQ & $x$ & $\sqrt{ }$ & + & Confirmed \\
\hline Sixth & DP & MS & $\sqrt{ }$ & $x$ & - & Not-confirmed \\
\hline
\end{tabular}

\section{Conclusion}

In this paper, we have presented an empirical investigation to study the impacts of six factors on default probability in Iranian banking sector. The proposed study has gathered the necessary information from most private and governmental banks in Iran. The study has implemented logistic regression technique to examine different hypotheses. The results of logistic analysis on relationship between default probability and six independent variables including capital adequacy, asset quality, management quality, earning quality, liquidity quality and sensitivity of market risk have indicated that there were no meaningful relationship between default probability and three independent variables including capital adequacy, asset quality and sensitivity of market risk. However, the results of our statistical tests supported such relationship between default probability and three other variables including management quality, earning quality and liquidity quality.

\section{References}

Basel Committee on Banking Supervision. (2005). International Convergence of Capital Measurement and Capital Standards, Revised Framework.

Bessis, J. (2005). Risk Management in Banking, Edition Five.

Boyes, W. J., Hoffman, D. L., \& Low, S. A. (1989). An econometric analysis of the bank credit scoring problem. Journal of Econometrics, 40(1), 3-14.

Chiu, L. (2005). Study and comparison of default rates of defaulted enterprises. JCIC Risk Research Team.

Fiordelisi, F., Marques-Ibanez, D. \& Molyneux, P. (2010). Efficiency and risk in European banking, working paper no 1211, European central bank.

Osherson, D. N., Stern, J., Wilkie, O., Stob, M., \& Smith, E. E. (1991). Default probability. Cognitive Science, 15(2), 251-269.

Vassalou, M., \& Xing, Y. (2004). Default risk in equity returns. The Journal of Finance, 59(2), 831868.

Zeitun, R., Tian, G., \& Keen, K. (2007). Default probability for the Jordanian companies: A test of cash flow theory. International Research Journal of Finance and Economics, 8, 147-149.

Zhou, C. (2001). An analysis of default correlations and multiple defaults. Review of Financial Studies, 14(2), 555-576. 